\title{
PLAY WHILE WRITING: BREAKTHROUGHS FOR DIGITAL LITERACY ACTIVITIES DURING THE COVID-19 PANDEMIC
}

\author{
Aswan \\ Departemen Pendidikan Bahasa dan Sastra Indonesia \\ Universitas Pendidikan Indonesia \\ hikayatashwansha@upi.edu
}

Received: 5th of September 2020, Accepted: $19^{\text {th }}$ of October 2020, Published: $4^{\text {th }}$ of December 2020

\begin{abstract}
Covid-19 presence in the world has paralyzed the education system. Indonesia became one of the countries affected by Covid-19. The education system, which is usually conducted face-to-face, is forced to go online to reduce the risk of contracting the Covid19 outbreak. Literacy activities that are considered important in schools are also affected by Covid-19. Seeing these problems, this study aims to create a literacy learning model that focuses on writing activities. The writing learning model with the play approach is a renewal in online writing activities. The method used in this research is qualitative. The sampling technique used is purposeful sampling. The data analysis technique used is an interactive analysis model from Miles and Huberman. Informants in this study amounted to 30 people consisting of students and the public. The Play While Writing Model starts with the conditioning of the class, the provision of relevant material, the instructions for playing, the process of playing while writing, the feedback from the informants, and the closing. The estimated online learning time is approximately one hour and thirty minutes. The results showed that the online writing learning model with a playful approach could attract informants. The writing learning model Playing While Writing makes students active, creative, and eager to express ideas in writing. As a whole, it can be said that the learning model of Playing While Writing can be a breakthrough in digital literacy during the Covid-19 pandemic.
\end{abstract}

Keywords: writing skills, digital literacy, Covid-19

\begin{abstract}
Abstrak
Kehadiran Covid-19 di dunia ini telah melumpuhkan sistem pendidikan. Indonesia menjadi salah satu negara yang terdampak Covid-19. Sistem pendidikan yang biasanya dilakukan secara tatap muka dipaksa menjadi daring untuk mengurangi resiko tertular wabah Covid-19 ini. Kegiatan literasi yang dianggap penting di sekolah juga terdampak Covid-19. Melihat permasalahan tersebut, penelitian ini bertujuan untuk menciptakan sebuah model pembelajaran literasi yang berfokus kepada aktivitas menulis. Model pembelajaran menulis dengan pendekatan bermain merupakan pembaharuan dalam aktivitas menulis yang bersifat daring. Metode yang digunakan dalam penelitian ini adalah metode kualitatif. Teknik sampling yang digunakan adalah porposive sampling. Teknik analisis data yang digunakan adalah model analisis interaktif dari Miles dan Huberman. Informan dalam penelitian ini berjumlah 30 orang yang terdiri dari siswa, mahasiswa, dan umum. Model Bermain Sambil Menulis dimulai dari pengondisian kelas, pemberian materi yang relevan, penginstruksian tata cara bermain, proses bermain sambil menulis, timbal balik dari informan, dan penutup. Estimasi waktu pembelajaran daring ini kurang lebih satu jam tiga puluh menit. Hasil penelitian menunjukan bahwa model pembelajaran menulis daring dengan pendekatan bermain dapat menarik minat informan. Model pembelajaran menulis Bermain Sambil Menulis membuat siswa aktif, kreatif, dan bersemangat menuangkan ide dalam tulisan. Secara keseluruhan dapat dikatakan bahwa model pembelajaran Bermain Sambil Menulis ini dapat menjadi sebuah terobosan baru dalam berliterasi digital di masa pandemi Covid19.
\end{abstract}

Kata Kunci: keterampilan menulis, literasi digital, Covid-19

Copyright (C) 2020 Aswan 


\section{INTRODUCTION}

The deadly and contagious disease is now known as Covid-19. This outbreak has profoundly affected all areas globally. Not only in Indonesia but also world citizens. The Covid-19 outbreak has completely devastated the world education system. According to Dhawan (2020), tragedies that hit the world today tend to resonate in the education sector globally. The Covid-19 pandemic outbreak has forced schools and colleges to temporarily close. Humans must keep their distance so as not to contract the deadly virus called Covid-19.

Pawar (2020) revealed that the Covid-19 outbreak was not indiscriminate because anyone could be infected. From adults to children, it is very easy to get infected by Covid-19. One of the efforts made by all countries to slow down the movement of the spread of Covid-19 is to maintain distance and cleanliness.

According to Boeren et. al. (2020), the Covid-19 pandemic has killed major sectors of the economy as well as the entire education system in the world. Besides, UNESCO also revealed that approximately 90 percent, especially students in the world, do not attend school face-to-face. Simply put, Covid-19 has paralyzed the education system that is carried out normally, namely by converting meetings in class to online.

One solution that can be done by countries in the world is to continue learning, but it is implemented online. This is true all over the world who want to keep the world of education alive. Digitalization is the main aspect of learning. Both teachers and students must be able to take advantage of digital platforms as a means of connecting long distances. This applies not only to the primary and secondary levels but also to the tertiary level. Tesar (2020) said that the Covid-19 outbreak forced academics to look for the right method to support the world of education. Academics inevitably have to take advantage of the current digitalization in implementing learning. Correspondingly, O'Sullivan et. al. (2020) also stated that internet access and digitalization of technology are currently very important for social equality, especially in the field of education.

Indonesia is one of the countries affected by the Covid-19 outbreak. The education system in Indonesia has changed drastically. The Covid-19 outbreak not only has an impact on formal education in schools, but also has an impact on extracurricular activities, school literacy movements, and so on. Teachers are forced by circumstances to look for new methods of online learning. Students are also forced to adapt to online learning. The internet and digitalized forms of teaching materials are the main capital in learning. Liguori and Winkler (2020) also state that the global spread of Covid-19 is a challenge for the educational landscape to utilize technology as a means of learning.

According to Liu and Doan (2020), the Covid-19 pandemic has produced high levels of stress and anxiety and can last a long time. This is vulnerable to impacting children, adults, and even elderly 
people. This is happening all over the world. This is based on keeping a distance to stop this outbreak. All humans must do their work from their respective homes. Teachers teach from home and students learn from home. This can cause excessive stress and uncontrolled anxiety.

Seeing the Covid-19 outbreak that has yet to find a stopping point, this research aims to create a game that can revive a digital platform-based literacy culture during the Covid-19 pandemic. In line with this, Blis (2019) reveals that today's digital technology and tools offer interactive and educational experiences. This should be the basis for any learning that makes digital the most important aspect. According to Kustini (2020), this growing era demands that humans be close to digital, including literacy education. Aulia et. al. (2020) states that in the development of this increasingly fast era, humans are required to combine literacy with technology, especially in literacy activities.

Seeing the problems during the Covid-19 pandemic, which was very complex. Researchers try to create a game model in writing activities using the WhatsApp application as the main media. The use of the WhatsApp application as a medium for writing activities is in line with the assumptions of Hutami and Nugraheni (2020) who state that the WhatsApp application has many functions, including sending messages both individually and in groups. Besides, through the WhatsApp application, users can send photos, videos, voice recordings, and even documents. When viewed from its usefulness, the WhatsApp application is suitable to be a medium for online learning in Indonesia.

The game designed is entitled "Playing While Writing". This game is implemented in Aryasena Publisher writing community. This research hopes to create a breakthrough in digital literacy activities during the Covid-19 pandemic. In line with the researcher's idea, Blikstad-Balas et. al. (2018) argued that to realize good writing activities, a supportive environment is needed. A supportive environment will provide writing opportunities for novice writers to express their ideas. Also, Cahyani and Hadiyanto (2019) stated that learning writing skills should be fun to create an active, creative, and innovative society. One solution so that Indonesians can compete globally is to improve their literacy culture, one of which is writing skills (Aswan, 2020).

Why do writing games are needed? Especially in digital literacy activities. This is based on the assumptions of Sunendar et. al. (2014) which states that writing skills are skills that have a very high level of complexity. Writing skills are very difficult language skills when compared to other language skills. This is also in line with Abdurrahman (2009) who stated that this writing skill is related to all aspects of language, such as reading, listening, and speaking. This is what requires humans to think critically and to sharpen human responsiveness and perception.

Previous and relevant research related to digital literacy during the Covid-19 pandemic was studied by Sutrisna (2020) entitled "The Literacy Movement during the Covid-19 Pandemic. This research reveals that during the Covid-19 pandemic, every individual must master and have digital 
literacy skills to participate in modern life and be able to anticipate incorrect information. This digital literacy movement is considered important because it demands that all social structures have a creative and critical view.

Latip (2020) also recently examined the role of literacy during the Covid-19 pandemic. The study entitled "The Role of Information and Communication Technology Literacy in Distance Learning during the Covid-19 Pandemic". This research reveals that distance education carried out during the Covid-19 pandemic must inevitably use technology in continuing educational ideals. Technology is the key to all learning activities, including literacy education. This study reveals that literacy related to information technology has an important role in facilitating distance education and the most basic thing is digital literacy.

Research related to digital literacy has also been studied by Irhandayaningsih (2020) entitled "Measuring Digital Literacy in Online Learning Participants in the Covid-19 Pandemic Period". This research reveals that digital literacy competencies play an important role in the implementation of online learning that applies during the pandemic. This should be the basis for all aspects of learning that have taken place during the Covid-19 pandemic.

If it is examined more deeply related to previous studies that have been presented. Broadly speaking, it can be said that previous research only emphasizes the problems of how to take advantage of digital literacy during the Covid-19 pandemic. As for what distinguishes the research that the researchers conducted, it is in terms of the usefulness of digital literacy which is used to support writing activities. This research is important to do because until now there has not been found an appropriate method or model, especially in digital literacy activities. It is hoped that this research can provide input to literacy activists to continue realizing literacy even though Covid-19 is still endemic in Indonesia.

In line with the aims and objectives of the researcher, Hanik (2020) in his research entitled "Self Directed Learning Based on Digital Literacy during the Covid-19 Pandemic Period at Madrasah Ibtidaiyah" revealed that the implementation of educational policies during the Covid-19 epidemic requires educators or policymakers to do innovation in learning. One of them is in digital literacy, everyone is expected to be able to add skills and knowledge to use digital platforms. From this, it is hoped that every digital product user can find information, make use of it, create information, and evaluate it. From these digital literacy activities, it is hoped that everyone will be able to develop even though Covid-19 is still endemic.

Based on the background and relevant research, this research is important to do. This is based on the urgency of literacy that is required to take advantage of digital platforms as an effort to revive the culture of literacy in Indonesia. Seeing that Covid-19 is still endemic, one way to turn on the literacy movement is by presenting an online learning model that is easy to accept and understand. 
This condition requires a pleasant literacy method. Therefore, the solution that the researcher offers is to create a literary model in writing activities entitled "Playing while Writing". Based on research and research, these models and methods have never been used and researched by researchers in the world, so that this research can be guaranteed its quality and originality.

\section{METHOD}

The method used in this research is a qualitative method. According to Meleong (2012), a qualitative research method is a method that produces data analysis procedures that do not use statistical procedures models. The choice of this method is adjusted to the objectives to be achieved in the research. The main purpose of this research is to describe how the game model "Playing while Writing". Besides, this research will also explain how to implement the model according to the expected procedural model. The final goal to be achieved is to describe the reciprocity of the simple application of the "Playing and Writing" model of the informants who were the samples in this study. This is following the assumptions of Arikunto (2013) which states that the data generated from qualitative research are descriptive. Simply put, this study focuses on describing how to implement the Playing and Writing learning model in digital literacy activities. The feasibility of this concept and model will be seen from the responses of the informants.

The informants in this study were participants who joined an online writing class held by Aryasena Publisher. The total population in this study was 200 people. However, researchers took 30 people to be the research sample. The background of the informants consisted of junior high and high school students (10 people), students (10 people), and general (10 people). The informants who are part of the online writing class organized by Aryasena Publisher come from all over Indonesia.

The sampling technique used in this study was purposeful sampling. According to Sugiono (2015), the purposive sampling technique is a technique of taking data samples by considering certain things. Certain things are adjusted to the objectives of this study. The researcher's considerations are: 1) informants can access the internet at a predetermined time; 2) informants understand the instructions described by the researcher; 3 ) informants are willing to take online writing classes from start to finish; and 4) informants are willing to provide feedback from the application of the learning model to write "Playing while Writing".

The main technique used in data collection in this study is to use the recording, listening, and note-taking technique. Record and record techniques are used in selecting data to be used in research. To obtain data in the form of an overview of the digital literacy movement via WhatsApp, the researchers recorded all the activities that occurred. This is to make it easier for researchers to describe the learning situation to play and write. Besides, the listening technique is used to pay attention to 
interesting things during the literacy movement, while the note-taking technique is used to note important points during digital literacy activities.

The data analysis technique in this study used an interactive model from Miles and Huberman (1994). This interactive model data analysis technique consists of data reduction, data presentation, and drawing conclusions or verification. At the data reduction stage, the researcher collected research data according to the procedural design that had been designed. At the data presentation stage, the researcher presented the data to be discussed and studied descriptively. As for the verification stage, the researcher states the conclusions from the results of the main analysis that have been described.

\section{FINDINGS AND DISCUSSION}

\section{Procedure for Playing while Writing}

The Playing and Writing Model is a game specially created for online writing classes held by Aryasena Publisher. This online writing class is conducted open to the public with the criteria of wanting novice writers. With the background of participants who do not have a basis in writing knowledge, efforts are needed to stimulate participants to absorb the information presented. The science of writing is practical. Therefore, we need models of writing activities but they do not explicitly look like learning. Therefore, a learning model was created for the digital literacy movement to stimulate participants to write. This play while writing model has also been used by Stagg Peterson and Rajendram (2019). However, this model is only used in face-to-face learning, meaning informal situations, whereas this study using WhatsApp as a medium because it is adapted to the current situation, namely the Covid-19 pandemic.

This model is designed for online learning by literacy activists. This writing learning model was created to attract participants with backgrounds who are not familiar with writing. As explained by experts that writing skills are the most difficult skills among all skills. Therefore, this writing learning model is presented in online writing classes. The keyword playing in this writing learning model is an attraction for online writing class participants because in general online classes are one-way. The writing learning model with the play approach is usually used in children aged 3 to 11 years in elementary school (Amorim, et al., 2020; Bendiksen, et, al., 2019; Burrell, \& Beard, 2018). This concept certainly shows a fundamental difference in that the play and writing model was created specifically for use during a pandemic without limiting the age of the participants.

Play while Play is created to create two-way classroom conditions that are interactive, creative, and fun. Playing while Writing is a writing activity that uses a sentence chain approach as a means of pouring out the ideas of the participants. Playing while Writing requires each participant to express ideas according to predetermined rules. Playing while Writing is a game on the continuation of 
sentences until it becomes a whole paragraph. This game uses key sentences that have been determined by the researcher as the opening sentence. Each participant must compete to connect the sentences set by the researcher. The sentences connected by the participants must create a picture of the story. The flow of the playing while writing an online learning procedure is described as follows.

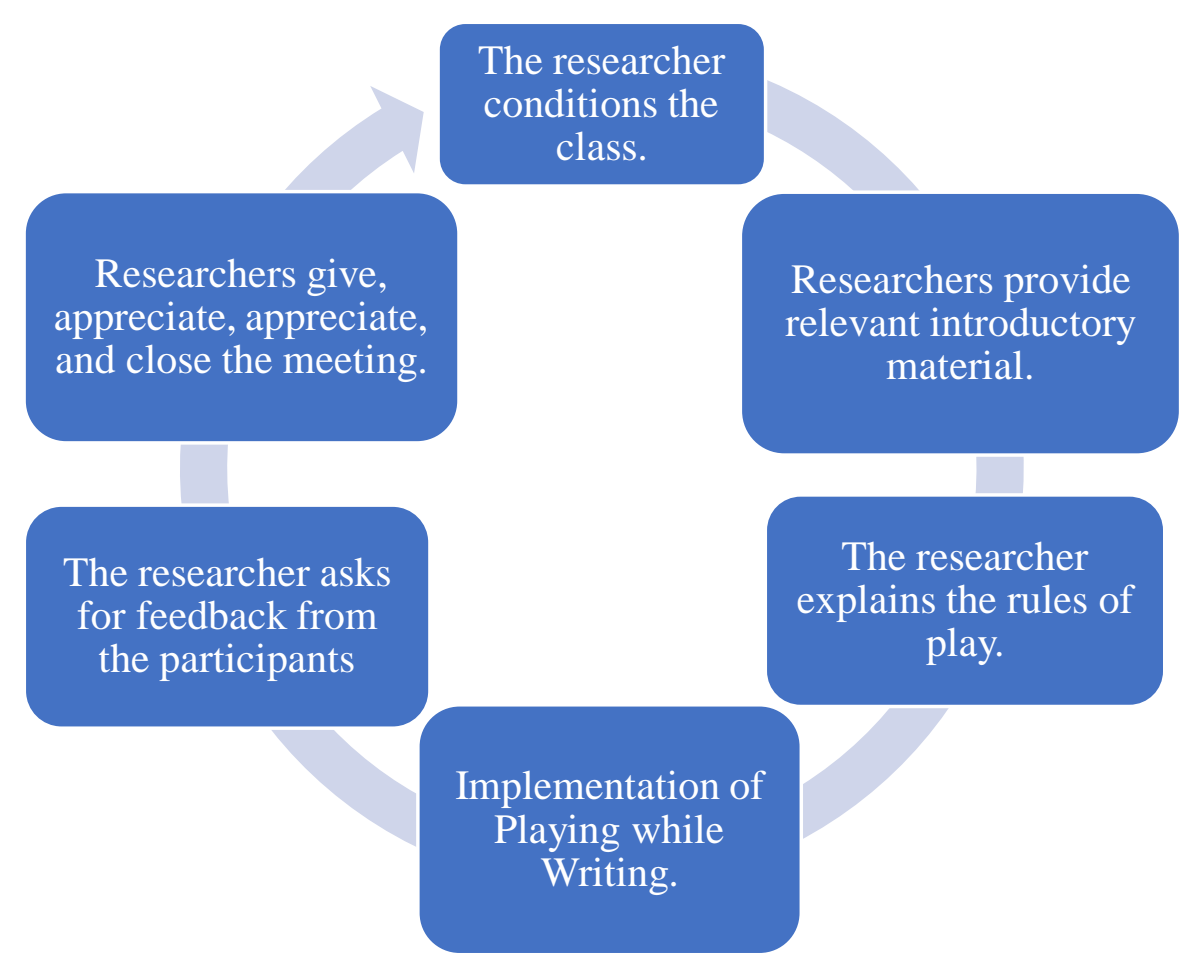

Figure 1. The Procedure for Implementing Playing and Writing

The first stage in learning to play while writing is the researcher as a resource in an online writing class held by Publisher Aryasena acting as the person who organizes the learning. However, for this online writing class learning to be conducive, the publisher assigns a participant who is not an informant to be the moderator. Researchers and moderators work together in conditioning the class so that the flow of learning to write Playing while Writing runs well. The estimated time at this stage is approximately 10 minutes.

The second stage of learning to write Playing while Writing is to bring the class to life by providing introductory material. Introductory material that researchers provide about common mistakes in writing. These mistakes are in the form of misuse of capital letters, punctuation, and so on. This is necessary to increase their knowledge before writing activities. The provision of this material is designed to run from two directions. First, researchers provide cases as a stimulus to participants. For example, in the concept of writing capital letters, the researcher provides a sentence that has errors. For example, in the sentence, Siti lives in the desa meninjau. From this sentence, there is an error in 
the word desa meninjau, it should be written as Desa Meninjau. This is what is expected to be a twoway discussion from researchers and participants so that the class becomes active. This introductory material is needed to stimulate informants in writing sentences and avoid common mistakes. The estimated time at this stage is approximately 15 minutes.

The third stage is the transition stage to enter the Learning-by-Playing game model. At this stage, the researcher and the moderator explain the systematics simply and understandably to the participants. At this stage too, the researcher and the moderator explain what can and cannot be done during the game. This is important because their understanding of this game supports the success that the researchers want. The estimated time at this stage is approximately 10 minutes.

The fourth stage is the core activity of this online writing learning model playing while writing. Participants who become informants in this study must follow the game from start to finish. The estimated time used is approximately 35 minutes.

The fifth stage is the stage that determines the description of the results of the participants writing online. At this stage, participants are asked to provide feedback from the online writing activity that has been followed. The results of this feedback are important to see how useful the Playing and Writing model is from the informant's point of view. The estimated time used is approximately 10 minutes.

The sixth stage is the last stage of all stages of literacy activities through the WhatsApp digital platform. At this stage, the researcher gives apperception, appreciation, and closes the meeting. This stage is needed to motivate the participants to keep writing and to be enthusiastic in literacy. The estimated time used is approximately 10 minutes.

These steps have been adapted to writing learning in general which includes opening, core activities, and closing (Wati, et al., 2020). There are also other versions of the stages, for example starting from planning, implementation, and evaluation (Hidayat, 2020). Basically, these two versions are the same because in essence a learning activity must be planned, implemented and evaluated.

\section{Implementation of Playing While Writing}

The writing learning model for digital literacy activities was held on July 15, 2020. Literacy activities were carried out from 18.30 until 20.00 WIB. online writing class participants who became informants came from Sabang to Merauke. This class is quite multicultural. Apart from different geographic backgrounds, the informants were also divided into three statuses, namely student, student, and general. This category was chosen to see how the conditions of participation in literacy activities from different social backgrounds.

The rules and procedures for playing are as follows: 1) each participant must connect the sentence provided by the researcher; 2) each participant has one chance to connect sentences in one round of play; 3) the change in the game round is indicated by no one connecting the sentence for two minutes, 
so the informant who has written can write again; 4) each participant must stick to the key sentence; 5) the sentence can consist of direct or indirect sentences; 6) a paragraph can only contain a maximum of eight authors; 7) the ninth writer must make a new sentence start if the previous sentence is fulfilled.

Besides the rules and procedures, the researcher also gave keywords in the form of the characteristics of the story that should be created. This is intended as signs in writing. Each participant must pay attention to the keywords or characteristics that have been set. This is important so that the stories built from 30 participants have unity so that they are worth reading. The characteristics or story grids that they must follow are: 1) theming about women; 2) the first-person point of view; 3) are narrative essays; 4) can use forward or reverse grooves; and 5) free background.

Table 1. Key Sentences

Seandainya aku tak lari, mungkin aku sudah menjadi istri keduanya.

Translate

If I didn't run away, I might have become his second wife.

From the key sentences set by the researcher, participants must compete to continue the sentence. The estimated time given is 35 minutes. Each participant must pay attention and read every sentence written by other participants. It aims to summon the imagination of the participants who are waiting for their turn to connect the next sentences. Here are the results.

If I didn't run away, maybe I would have become his second wife (stimulus). (1) I thought he was a nice guy and had no ties to anyone other than me, but it turns out that he already has a family. (2) I'm stupid still thinking about him. (3) This love made me insane. How come? The person I trusted It turned out that from behind he had betrayed me. (4) But this heart still loves him. (5) I should be able to forget it. (6) Even if it's hard, I'll do it. (7) I thought again, why all this had to happen to me.

(8) Years after years, I slowly managed to erase my feelings for her. (9) However, when I opened the cellphone, I saw the photo. (10) I hit the delete button so I can forget about it. (11) It's useless, I can't hold back these tears. (12) I wanted to tell you about my feelings, but I'm embarrassed. (13) I just wrote it in my diary book and asked for guidance from those in power, unable to forget it either. (14) maybe I already love him, so it's hard to just forget about him. (15) What else should I do?

(16) Sapri, the name of a man that is carved beautifully in the recesses of my heart. (17) A name that's hard to erase in my memory. (18) But it's always on a piece of paper in my diary. (19) He is a silent witness to my story with him. (20) So, one day I can recall that there was a boy who made it difficult for me to forget. (21) Right now, I will focus on rearranging the pieces of the heart that were torn and left open. (22) I want my future to be more beautiful with the right person. 
(23) And, now I know that what I have experienced so far has taught me to be a man who is tough, strong, and always be patient with all this. (24) God is so good the sorrow is passed. (25) In front of me now, stands a man whom I did not expect to make my feelings for Sapri completely disappear. (26) He is Rafa, it is he who has changed my life for the better. (27) The more I get to know Rafa, the deeper the feelings I have been holding onto. (28) I don't know but the fear of losing is so strong. (29) She's so cute on my mind lately. (30) then what should I do?

It can be said that using a game model in writing activities for novice writers is a solution that can be offered to literacy activists. This can be seen in the stories produced by the participants. Each participant succeeded in connecting sentence by sentence from different people. The key characteristics that have been determined become a reference for all participants in writing.

The 35 minutes used in implementing the writing learning model for literacy activities were used well by the participants. With a system of competing sentences, the participants looked excited. This can be seen in the notification section of the typing screen that never stops in the WhatsApp application.

Before closing learning to write online, the researcher spontaneously asked the informants to give a title to the writing they had written together. The titles they give are: "Romanda Cinta"; "Me, Sapri, and Rafa"; "Life That Is Not on My Side"; "The bitter story that I experienced"; "Sweet Bitter Life"; "The Story of Tie My Heart"; "My Story and Him"; etc. From the process of finding ideas for creating titles, they seem very enthusiastic and active in participating in this online writing class.

\section{Informant Reciprocity Representative}

Informants who participated in online writing classes provide very positive feedback. On the characteristics of informants with status, students said that they had new experiences in writing. Besides, the informants were happy with the writing learning model for digital literacy activities like this. From start to finish, they are interested in the flow of the Play while Writing model. The following is one of the responses of an informant who is a student, "Alhamdulillah, it is great to be able to join the writing class today, a lot of new knowledge has been gained regarding writing. InsyaAllah, the knowledge gained from this class will be very beneficial for me." The informant with the initials FK.

Learning to write, which is difficult, seems to be happy when using the right methods. This is reflected in the feedback from the informant's status as a student. The informants who hold student titles feel helped by the existence of this writing learning model, playing while Writing. They also say that they have the opportunity to come up with ideas in their way but stay on the storyline. Besides, they feel motivated to continue working. Classes are online which are usually synonymous with boring, but that is not the case with this Play while Writing model. The informant felt like he was 
learning face to face. They do not feel bored in taking this online writing class. The following excerpt, "Usually writing class is synonymous with 'boring' in my opinion, especially online classes. However, this time it was truly extraordinary. Even though it's online, it's fun and enjoyable. Yes, because we learn while playing. Online alone is amazing what if offline, hehe. " The informant with the initials AS.

Not much different from the status of participants who came from the general category. In this group, the informants felt that the Playing While Writing model was very useful to help them word for word. Besides, they feel that this writing learning model makes it easier for them to express ideas because it is stimulated by key sentences. The following is an excerpt, "Alhamdulillah, the knowledge is useful and interesting. It doesn't taste like material, because it's playing." The informant with the initials LF is a housewife.

This is in line with the theory of experts who say that writing activities should be supported by the environment. This is intended to motivate literacy communities in writing. Especially for digital literacy activities, new things must be done so that they are not monotonous and boring. As revealed by the informants, the writing learning model is playing while writing is very useful in helping them express their writing ideas.

\section{Research Findings}

Based on the explanation that has been done, there are several findings in this study. First, WhatsApp, which is known as a messaging application, can be used as a medium for digital literacy activities. This is certainly a breakthrough in the world of education today that in a pandemic like this, learning media that can be used are needed. In this study, it was found that WhatsApp can be used as a medium of learning in general and in particular for digital literacy activities. The results of this study are the same as those of Dahdal (2020) and Annamalai (2019) that WhatsApp can be used by educators with students in learning. However, what distinguishes this research from the research conducted by Dahdal is the scope of its utilization. Research conducted by Dahdal was used to conduct discussions while for this study using WhatsApp as a medium for the digital literacy movement.

Second, the literacy model of playing while writing is a breakthrough during the Covid-19 pandemic. This is due to the usefulness of WhatsApp as a multifunctional medium. According to, Batra (2016) revealed that WhatsApp, which has been downloaded by more than one billion worldwide, is not only a medium for communication but can be used as a learning medium. Research conducted by Batra is the same as this research, namely, WhatsApp is a very fun medium because it has many features. Research conducted by Mena Guacas and Santoveña Casal (2019) also revealed that the WhatsApp application is not only multifunctional but can be used in two-way communication in learning without eliminating elements of the academic context. What distinguishes the results of the 
research that has been carried out is in terms of its use, previous studies have focused more on formal context learning. So, WhatsApp is limited to being used in formal learning and normal situations, while this research uses WhatsApp for more external learning, namely digital literacy activities under the conditions of the Covid-19 pandemic.

Third, the benefits of WhatsApp for the digital literacy movement. The findings in this study explain that WhatsApp has useful value as a learning medium. This is because WhatsApp has many functions such as sending pictures, videos, and so on. The function of this application may exist in various other applications, but WhatsApp is still the favorite application for anyone in this world. This finding is a breakthrough in driving digital literacy activities, especially during the Covid-19 pandemic. Research is very rare that reveals how WhatsApp is used as a literacy medium. As for previous research such as that conducted by Radovanović, et al. (2015) became Facebook as a literacy medium, in contrast to the research of Choi and Behm-Morawitz (2017) and Tan (2013) which made Youtube a literacy medium, while research conducted by Wahyudin and Adiputra (2019) utilized Instagram in digital literacy activities. Based on these studies, it is clear that the researcher's findings are a breakthrough, namely using WhatsApp as a medium for digital literacy activities during the pandemic with the theme of playing while writing.

\section{CONCLUSION}

Based on the research results that have been described in the discussion section, conclusions are obtained, namely as follows. The design of learning to write for digital literacy activities in online writing classes through the play approach can be a breakthrough for literacy activities during the Covid-19 pandemic. The activities in the writing learning model for digital literacy activities start from conditioning the forum to be orderly. Followed by providing relevant material. After that, instructing the game rules and procedures. At the playing stage, participants must follow the game from start to finish. The game is to connect sentences into paragraphs, then become a story. After the play stage is over, participants are asked to give feedback on the activities that have been followed. The final stage is apperception, appreciation, then closing.

Feedback from informants was very positive. The existence of playing while writing online learning models for online literacy classes can help literacy activists in realizing a fun literacy movement. Also, the existence of this writing learning model helped informants. Besides, the Playing While Writing learning model makes them enthusiastic in writing. It can be said that this learning model of playing while writing can be a breakthrough in digital literacy activities during the Covid-19 pandemic. 


\section{ACKNOWLEDGMENT}

The highest appreciation goes to the publisher Aryasena for providing good cooperation in facilitating and supporting the research that the researchers have done.

\section{REFERENCES}

Amorim, A. N., Jeon, L., Abel, Y., Felisberto, E. F., Barbosa, L. N., \& Dias, N. M. (2020). Using escribo play video games to improve phonological awareness, early reading, and writing in preschool. Educational Researcher, 49(3), 188-197.

Annamalai, N. (2019). Using whatsapp to extend learning in a blended classroom environment. Teaching English with Technology, 19(1), 3-20.

Arikunto, S. (2013). Prosedur penelitian: Suatu pendekatan praktik. Jakarta: Rineka Cipta.

Aswan. (2020). Implementasi gerakan literasi sekolah di community learning center sebagai upaya meningkatkan kosakata bahasa indonesia siswa. KLITIKA: Jurnal Ilmiah Pendidikan Bahasa dan Sastra Indonesia, 2(1), 1-10. http://dx.doi.org/10.32585/klitika.v2i1.708

Aulia, N. L., Aswan., \& Naufalia, A. (2020). Pendidikan berbasis produk dalam meningkatkan literasi anak menuju generasi emas 2045. KLITIKA: Jurnal Ilmiah Pendidikan Bahasa dan Sastra Indonesia, 2(1), 55-64. http://dx.doi.org/10.32585/klitika.v2i1.709

Batra, B. (2016). News communication through WhatsApp. International Journal of Informative \& Futuristic Research, 3(10), 3725-3733.

Bendiksen, S. Å., Østern, A. L., \& Belliveau, G. (2019). Literacy events in writing play workshops with children aged three to five: a study of agential cuts with the artographic triple dimensions as a lens. International Journal of Education \& the Arts, 20(3).

Blikstad-Balas, M., Roe, A., \& Klette, K. (2018). Opportunities to write: An exploration of student writing during language arts lessons in norwegian lower secondary classrooms. Writing Communication, 35(2), 119-154. https://doi.org/10.1177/0741088317751123

Bliss, A. C. (2019). Adult science-based learning: The intersection of digital, science, and information literacies. Adult Learning, 30(3), 128 -137. https://doi.org/10.1177/1045159519829042

Boeren, E., Roumell, E. A., \& Roessger, K. M. (2020). COVID-19 and the future of adult education: An Editorial, 70(3), 201-204. https://doi.org/10.1177/2516602620938542

Burrell, A., \& Beard, R. (2018). Playing with words: investigating the use of language play in the persuasive writing of 9-11-year-olds. Education 3-13, 46(2), 202-217.

Cahyani, I., \& Hadianto, D. (2019). Keterampilan menulis dengan model pakem melalui teknik 'menjadi wartawan junior' di sekolah dasar. Jurnal Pendidikan Bahasa dan Sastra, 19(2), 139_ 149. https://doi.org/10.17509/bs jpbsp.v19i2.24781 
Choi, G. Y., \& Behm-Morawitz, E. (2017). Giving a new makeover to STEAM: Establishing youtube beauty gurus as digital literacy educators through messages and effects on viewers. Computers in Human Behavior, 73, 80-91.

Dahdal, S. (2020). Using the whatsapp social media application for active learning. Journal of Educational Technology Systems, 49(2), 239-249. https://doi.org/10.1177/0047239520928307

Dhawan, S. (2020). Online learning: A panacea in the time of COVID-19 crisis. Journal of Educational Technology Systems, 1-18.: https://doi.org/10.1177/0047239520934018

Hanik, E. U. (2020). Self directed learning berbasis literasi digital pada masa pandemi covid-19 di madrasah ibtidaiyah. ELEMENTARY Islamic Teacher Journal, 8(1), 183-208. http://dx.doi.org/10.21043/elementary.v8i1.7417

Hidayat, M. T. (2020). Pembelajaran menulis teks prosedur dengan metode discovery learning pada siswa kelas vii smp negeri 1 langsa. Jurnal Samudra Bahasa, 3(1), 45-51.

Hutami, M. S., \& Nugraheni, H. S. (2020). Metode pembelajaran melalui whatsapp group sebagai antisipasi penyebaran Covid-19 pada AUD di TK ABA kleco kotagede. PAUDIA, 9(1), 126130. https://doi.org/10.26877/paudia.v9i1.6107

Kustini, S., Suherdi, D., \& Musthafa, B. (2020). Beyond traditional literacies: A multimodal-based instruction to fostering student digital literacy learning. Jurnal Pendidikan Bahasa dan Sastra, 20(1), 37-47. https://doi.org/10.17509/bs jpbsp.v20i1.25969

Latip, A. (2020). Peran literasi teknologi informasi dan komunikasi pada pembelajaran jarak jauh di masa pandemi Covid-19. EduTeach: Jurnal Edukasi dan Teknologi Pembelajaran, 1(2), 107115. 10.37859/eduteach.v1i2.1956

Liguori, E., \& Winkler, C. (2020). From offline to online: Challenges and opportunities for entrepreneurship education following the COVID-19 pandemic. Entrepreneurship Education and Pedagogy, 1-6. https://doi.org/10.1177/2515127420916738

Liu, C. H., \& Doan, S. N. (2020). Psychosocial stress contagion in children and families during the COVID-19 pandemic. Clinical Pediatrics, $\quad$ 59(9-10), https://doi.org/10.1177/0009922820927044

Mena Guacas, A. F., \& Santoveña Casal, S. M. (2018). Whatsapp and formulating guidelines on network interaction during the learning process in the university classroom. IJERI: International Journal of Educational Research and Innovation, 11, 121-136.

Miles, M. B., \& Huberman, A. M. (1994). An expanded sourcebook: Qualitative data analysis (second edition). California: SAGE Publishing.

Moleong, J. L. (2012). Metodologi penelitian kualitatif. Bandung: Rosdakarya. 
O’Sullivan, D., Rahamathulla, M., \& Pawar, M. (2020). The impact and implications of COVID-19: An australian perspective. The International Journal of Community and Social Development, 2(2), 134-151. https://doi.org/10.1177/2516602620937922

Pawar, M. (2020). The global impact of and responses to the COVID-19 pandemic. The International Journal of Community and Social Development, 2(2), 111-120. https://doi.org/10.1177/2516602620938542

Radovanović, D., Hogan, B., \& Lalić, D. (2015). Overcoming digital divides in higher education: Digital literacy beyond Facebook. New media \& society, 17(10), 1733-1749.

Stagg Peterson, S., \& Rajendram, S. (2019). Teacher-child and peer talk in collaborative writing and writing-mediated play: Primary classrooms in Northern Canada. Australian Journal of Language \& Literacy, 42(1).

Sugiono. (2015). Metode penelitian kuantitatif kualitatif dan $R \& D$. Bandung: CV Alfabeta.

Sunendar, D., Cahyani, D., \& Mulyadi, Y. (2014). Implementasi metode ecriture créative berbasis budaya lokal untuk meningkatkan keterampilan menulis bahasa perancis level B1 DELF. Jurnal Pendidikan Bahasa dan Sastra, 14(2), 230-241. https://doi.org/10.17509/bs_jpbsp.v14i2.721

Sutrisna, I. P. G. (2020). Gerakan literasi digital pada masa pandemi covid-19. Stilistika: Jurnal Pendidikan Bahasa dan Seni, 8(2), 268-283. https://10.5281/zenodo.3884420

Tan, E. (2013). Informal learning on YouTube: Exploring digital literacy in independent online learning. Learning, Media and Technology, 38(4), 463-477.

Tesar, M. (2020). Towards a post-covid-19 'New Normality?': Physical and social distancing, the move to online and higher education, Policy Futures in Education, 18(5), 556-559. https://doi.org/10.1177/1478210320935671

Wahyudin, D., \& Adiputra, C. P. (2019). Analisis literasi digital pada konten instagram@ infinitygenre. wacana: Jurnal Ilmiah Ilmu Komunikasi, 18(1), 25-34.

Wati, N. M. A., Rasna, I. W., \& Martha, I. N. (2020). Penerapan model pembelajaran pailkem untuk meningkatkan kemampuan menulis teks eksplanasi. Jurnal Pendidikan dan Pembelajaran Bahasa Indonesia, 9(1), 13-25. 